\title{
第1回 エレクトロニクスにおける環境技術シンポジウム報告
}

\author{
Report of the 1 st Symposium on Environmentally \\ Conscious Engineering in Electronics
}

本多進*

LCA 日本フォーラムほか 2 団体共催, 当協会ほか 19 団体協賛による日本初の掲題のシンポジウムが 7 月 9〜11日, 東大・山上会館で開催された。以下にその概 要を報告する。

初日は実行委員長, 東大・須賀唯知教授の挨拶に続き, 組織委員長, 東大 - 山本良一教授の基調講演「地球環境 と資源」で開幕した。世界人口の急増は資源の枯渇化と 環境悪化をもたらす。対策はエコデザインの開発, LC $\mathrm{A}$ によるエコプロダクトの推進と環境コストの負担に あるとの見解が述べられた。

続く「海外動向」では, 欧州の廃家電品処理システム, ドイツ環境法と企業の取組状況, 電子機器の効率的りサ イクルを狙ったEUREKA Project-CARE “VISION 2000”の視察報告と IEEEのエレクトロニクスと環境国 際シンポジウム報告が行われた。これら欧米の活動には 学ぶところが多い。

早大・永田勝也教授の基調講演「リサイクル設計と LCAの動向」では，製品アセスメントの定量評価を目 指す LCA 手法では統合評価が重要との見解が述べられ， 続く「LCA」で同教授研究室から，アンケート調查に 基づく指標統合化手法が報告された。さらに，LCAの 簡易評価法や環境統合ソフトの開発例も報告された。

次の「環境調和型製品 (ECP)」では，エコマテリア ルの開発，製造から廃亲までを指数化し，その総和でグ リーンコンシューマ評価値とする ECP 導入促進調査委 員会の紹介, さらに家電, 移動体通信, OA 機器の ECP 開発事例やエコデザインコンセプトモデルが報告 された。なお，翌日の解体性関係の 2 件が繰り上り，デ イスアセンブリ性の定量評価法と常温接合による可逆的 接続技術の開発状況が報告された。

2 日目の「低環境負荷実装技術」では, $\mathrm{Cu}, \mathrm{Pb}, \mathrm{Sn}$ と錯体を作り，水に不溶の有機酸を用いた無洗浄用フラ
ックスの開発，はんだからの鉛溶出は表面組成や粗さ， 酸化状態に左右され, 機器の使用環境や年数依存度が大 きいとする報告, 廃棄配線板からの銅の湿式溶解一電解 回収とその他金属の中和沈殿回収による効率的リサイク ル法, 廃 TV 配線板のはんだを加熱し, 回転ブラシで 高純度回収する方法等の報告があった。

続く「鉛フリ一環境技術」は阪大・竹本正助教授の招 待講演「マイクロソルダリングにおける鉛フリー化」で 始まり, 融点は高いが高性能の $\mathrm{Sn}-\mathrm{Ag}$ 系が鉛フリーは んだ実用化の近道との見解が述べられ，続く発表でも， $\mathrm{Sn}-\mathrm{Ag}$ 合金は接合強度が $\mathrm{Sn}-\mathrm{Pb}$ 共晶の 2 倍近くあり有 望との報告や，すでに大型電算機のチップキャリア接続 に Sn-3.5Ag はんだを使用中との報告があった。

さらに，Sn-Zn-Bi， Sn-Ag-Bi はんだを検討中で，濡 れ性や融点等の面で改良中との報告や, $\mathrm{Sn}-\mathrm{Zn}$ 系はん だは濡れ性確保に窒素炉が必要で, チップ部品電極は $\mathrm{Sn} 100 \%$ より $\mathrm{Sn}-\mathrm{Bi}$ 等の合金めつきが良いとの報告があ った。

続く「リサイクル技術」では, 乾溜油化と触媒工程処 理による廃冷蔵庫のフロン含有ウレタン処理技術, PC 用 $\mathrm{Mg}-\mathrm{Al}$ 合金やコピー済み用紙のリサイクル法, マン ガン乾電池からのフェライト有効成分の回収による $\mathrm{TV}$ 用偏向ヨークへの再利用法等が報告された。

次の「低環境負荷処理技術」では, 廃液中の $\mathrm{Cu}, \mathrm{Ni}$, $\mathrm{Pb}$ 等の金属イオンの還元，凝集による簡便な金属回収 法や, 環境中の微量腐食性がス簡易测定法, トリクロロ エチレンや現像廃液の微生物利用処理システムが報告さ れた。最後の「リサイクル設計技術」は 2 件が初日に回 って 3 件となり, リサイクル対応設計法やグリーンライ フサイクル設計法, 分解性評価法の開発とリサイクル製 品への適用法が報告された。

3 日目, 最初の東大・木村文彦教授の基調講演「イン

* Susumu Honda（SHM 理事, SHM 調査委員会委員長兼環境問題動向調查分科会幹事。(株エス・シー・ラボラトリー）

Vol.12, No.5 
バースマニュファクチャリングのためのライフサイクル モデリング」では基本概念の説明があり，続く「リサイ クルシステム」では, 家電製品協会と家電メ一カで推進 中の廃家電品一貫処理リサイクルプラントの進捗状況の ほか，廃製品のリサイクル／リユースシステムが，さら に「環境マネジメント」では取組み事例の紹介があった。 さらに招待講演でシーメンスの Dr. Felder から，世 界の先端を行く同社の環境事業への取組み状況が報告さ れ, 続く「環境と人工物工学」では, 東大・富山助教授 の招待講演「地球環境問題と産業システムのパラダイム シフト」で，人工物生産を中心とした来るべきポスト大
量生産パラダイムのあるべき姿が示された。続いて，同 助教授ほかからのモジュール型製品のライフサイクルシ ミュレーションによるパラダイム実現の可能性や，イン ターネットを利用したグリーンプラウザの研究紹介があ った。

最後の須賀教授の司会, 評論家・立花隆氏ほか専門家 5 氏による「環境技術の将来と課題」と題するパネルデ イスカッションは, 幅広い視点からの意見交換で盛り上 がり, 充実した 3 日間のシンポジウムをより有効なもの として閉幕した。

\section{新 刊 紹介}

\section{膜形成技術用語事典編集委員会・編 \\ (株)工業調査会（1996年 5 月発行） \\ A 5 判/本文394ページ/定価9785円}

現代の科学技術, 特にエレクトロニクスにおける特徴 は，膜技術を中心とした各分野の技術が相互に依存しあ っていることです。たとえば，半導体メモリでは，次々 世代の256M ビット DRAM において酸化タンタルがキ ヤパシ夕薄膜として使われようとしていますが，パッケ 一ジング工程での劣化が深刻な問題となっており, キャ パシ夕薄膜形成とパッケージングとの整合が要求されて います。

このように，デバイス開発を成功させるためには広範 囲な膜技術の情報を正確にとら之，的確な判断をする必 要があります。その前提として，膜技術に関する用語の 意味を正しく理解することは必須であります。

従来, 個々の膜技術に関寸る用語事典は数多く出版さ れていますが, 薄膜から厚膜まで多岐にわたる膜技術を 包含している事典は皆無でした。このような状況下，こ こに紹介する「膜形成技術用語事典」は，膜技術に従事 する人にとって待望の書であります。編集・執筆は研究 機関, 産業界で活躍されている各分野の専門家, 38人に より行われたものです。

\section{図解 膜形成技術用語事典}

本書は, 膜を「薄膜」と「厚膜」に分類しており, こ れより派生する多岐の項目（700以上）を取り上げてい ます。主要な項目は，「1.デバイス（ハイブリッド IC， ダイオード，磁気へッド，TFT)」「2. プロセス（パッ ケージング, めっき, バンプ, ボンディング, CVD, 蒸着)」「3. 材料 (基板材料, 薄膜材料, ペース卜)」「4. 装置（スキージィ，スクリーン印刷，真空ポンプ）」「5. 基礎物性 (熱伝導, 熱膨張, 粘度)」「6. 半導体物性 (エネルギ一带困, ショットキー接触, 移動度)」「7. セ ラミックス物性（格子欠陥, 転位, 共晶)」「8. 分析 (X 線回折, FTIR, EPMA)」「9. 試験（温度サイクル 試験，バーンイン，ボンドテス夕)」となっており，お よそ膜に関する全ての分野を網羅しています。

特徴としては，膜技術のバックボーンとなる物性の項 目が充実しており，膜に関する体系的知識が得られるよ う配慮されています。また用語の説明は具体的で，かつ 四面を多用しており，非常にわかりやすい内容となって います。

以上のように，この事典は，膜技術者，これから膜技 術を基礎から習得しようとする人にとって極めて有益で あり，座右の銘として推鹰します。

(SHM 編集委員会) 